\title{
The Authorities for the Case of Richard Hunne (I5I4-IS)
}

Most accounts of the case of Richard Hunne are based upon those given in Hall's Chronicle ${ }^{1}$ and Foxe's Acts and Monuments. ${ }^{2}$ Both these writers, however, reproduced the greater part of an anonymous tract, ${ }^{3}$ which in the original has a preface containing an allusion to the death of Tyndale, and therefore cannot be earlier than 1536.4 Hall, who includes in the list of authors from whose works he derived his chronicle, ' diuers Pamphlettes, the names of whom are to moste menne unknowen,' reprinted this one almost in full, though not accurately $;^{5}$ and Foxe transcribed Hall's version. ${ }^{6}$ One of the most serious errors in that version occurs in a sentence very often quoted, ${ }^{7}$ part of a letter ascribed to the bishop of London, which in the original runs :

. . assured am I if my Chaunceler be tryed by any xij. men in Londō they be so maliciouslie set in fauore hereticae prauitatis/that is ar so set apon the fauoure of heresie $/ \mathrm{y}^{\mathrm{t}}$ they will cast and condemne my clarcke / thowght he war as innocent as Abel.

Hall, or his printer, changed 'my' into 'any', and the mistake has remained current ever since.

Much that has been written, not only on Hunne's case, but on the problem of the amount of 'heretical pravity' existing in England at the beginning of the reign of Henry VIII is based directly or indirectly upon this tract; hence the question of its value as evidence is of some importance. One would be inclined to regard as of no value whatever the evidence of an anonymous pamphlet published more than twenty years after the events of

1 Under the year 6 Henry VIII.

2 Vol. iv, pp. 183 segq. of any one of the four complete editions published between 1837 and 1877, and variously known as Cattley's or. Townsend's or Pratt's.

- I pointed this out some years ago in the Victoria History of London, i. 247.

- The enquirie and verdile of the quest panneld of the death of Richard Hune wich was founde hanged in Lolars tower. I have discussed the date of this tract and given some bibliographical details in The Library, April 1914, p. 220. Only three or four copies are known to erist: two (one imperfect) in the British Museum, one in the library of Corpus Christi College, Cambridge, and part of one in that of St. Paul's Cathedral. All are of the same edition. The preface is an interesting expresion of anti-clerical feeling at a time when it was possible to write: "The light is now broken forth (thankes be to the Lorde) mager theire beardes/and they brought in no emall feare of sodaine ruine of theire kingdome/yet by cause they se the world hath not fully forsaken theire deceyuable doctrine in all places/they hope of a change/and haue theire secrete conspirisies denised with all sutteltie to bryng that to pas.'

- He omitted the preface and the marginal commente, and his version differs from the original in many details of wording besides those noticed.

- In the first edition of the Acte and Monumexts (1563) pp. 390 seqq. He made 8ome alterations in that of 1570 (ii. 934 seqq.), which are adopted in those of 1837-77 (iv. 190 segq.).

' The suthority for it now urually given is Letters and Papers, Henry YIII, I, no. 2, which summarizes Fore's version of the bishop's letter. 
which it treats, even if its internal discrepancies had not been declared inexplicable by Gairdner, ${ }^{8}$ after a close examination of the text. But some testimony in favour of two of its sections is furnished by the records of the Corporation of London. ${ }^{9}$ An entry in the minutes of the Court of Aldermen ${ }^{10}$ during the mayoralty of George Monoux (November 1514-15) runs as follows :

\section{Martis xvij ${ }^{\circ}$ die aprillis}

In Recorder Capell Haddon Aylemer Jenyns Atcheley Boteler Rest Exmewe Brugge Milburn Shelton Fenrother Grey Aleyn Yerford Mundy Vicecomites.

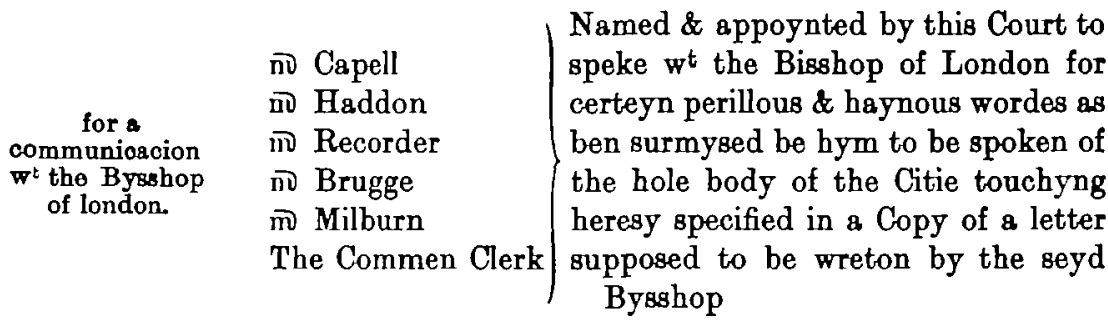

This shows that words not unlike those of the tract were in fact attributed to Bishop Fitzjames in April 1515."1 Also the details given in the coroner's 'Inquisition' with which the tract concludes are in accordance with the customs of the city ${ }^{12}$ regarding the number of jurors and their impanelling from particular wards - matters on which a writer trying to forge such a document would be very likely to go wrong. ${ }^{13}$ Moreover, the

- The English Church in the Sixteenth Century, c. iii, pp. 29-30 and passim. It is, however, clear, from the use that Gairdner himself, in his reconstruction of the story, made of the part of Hall's Chronicle consisting of the tract, that he did not regard ita evidence as altogether worthless, although his reasoning appears to lead to that conclusion. As he was unaware of the existence of the tract, he made Hall responsible for its defecto : 100 pp. 27 and 40.

- My acquaintance with these recorde is but superficial, and it is probeble that an exhaustivo search among them would throw further light upon Hunne's case.

1- Repertory $\mathrm{LI}$, fo. $17^{\circ}$. This entry has already been noticed in the Victoria Hiotory of London, i. 247, where the date 1517 should be 1516.

11 Gairdner (op. cit., p. 30) notices that the heading of this seotion of the tract describes Wolsey as cardinal, and must therefore be later than September 1515. But it may well have been added after that date, either as an endorsement on the original or by the compiler of the tract.

11 For these R. R. Sharpe, Calendar of Coroners' Rolls, p. xiv. The rolle for the eirteenth century have disappeared, except one dated 1500 (ibid. p. vii, note). Mr. A. H. Thomas, Dr. Sharpe's sucossor as records clerk, pointed out to me that the first phrase, of the document in the tract, 'The inquisicio intendend take...' must in the original have read 'The inquisition indented, taken ... and that with this correction its form is quite regular, except that it does not contein the customary last clause about the property of the murderer (at G. Jacob, New Laso Dictionary, ed. 1739, under 'Coroner'). It is curious that Hall, lawyer as he was, did not notice this : he or his printer altered the phrase to 'intendid and taken'

13 Hsll himself contradicts the tract he was about to reprint by stating ' $x i i$ men were oharged before the Coronour.' 
discrepancies noted by Gairdner ${ }^{14}$ would disappear if the first section of the tract, which he was led by its opening words to regard as the report of the jury drawn up at the inquest held in December 1514, could be dated two or three months later. Now Sir Thomas More says ${ }^{15}$ that the 'matter was many tymes in sundry places examyned ', especially one day at Baynard's Castle before 'dyuers grete lordes spyrytuall and temporall and other of the kynges honourable counsayle '; and Hall, that the jurors were 'many tymes ... wyth the kynges counsayll and hard their opynions'. This suggests that they were ordered to reconsider their verdict, and if so the compiler of the tract may have been asing the final report, very badly drafted, which they made to the council, and in which were combined a statement of the reasons for their original decision with copies of depositions afterwards taken which appeared to provide further justification for it..$^{18}$

It thus seems not improbable that the tract is a collection of genuine documents, with a preface and marginal notes added by the compiler. But it cannot be assumed that even in his version, much less in those of Hall and Foxe, they are accurately printed; and their statements, made at a time when the city was overwhelmed by a wave of excitement and party clamour, cannot be accepted without reserve. Hence the evidence of the tract is at best third rate, and might well be neglected in any general consideration of the state of religion in England at the beginning of the sixteenth century. It is not necessary even in dealing with the special case of Richard Hunne, since enough independent material exists for a coherent account of that, which might be based mainly upon records, some original, others, though only preserved in the pages of Foxe, almost certainly genuine.

Such an account would have to begin with some reference to three movements in which Hunne was involved : the attacks on ecclesiastical jurisdiction which culminated in the Parliament of 1515, the strife between the London citizens and their clergy on the question of offerings, and the undercurrent of Lollardy. For the first it is probable that most of the authorities, except the Journals of Parliament, are mentioned in vols. $i$ and ii of the Letters and Papers, Henry VIII ; but other material may exist, for example among the judicial and administrative records not included in that collection. For the second there is much material in

14 These are even more serious than appeared in the version he was using, for in the tract itself one of the depositions is deted 14 February 1514-15 $\rightarrow$ detail omitted by Hall and consequently by Fore.

16 Dyaloge, book iii, ch. Iv.

14 Compare their allusions to 'my Lorde of Londons booke' (i. e. statement of the ase), which could not have been drawn up till after the inquest, and to a witness whom the summoner, Charles Joseph, had already 'brought before the kynges councell'. 
the City records, ${ }^{17}$ some in those of the ecclesiastical courts of the diocese of London, ${ }^{18}$ two documents in the Letters and Papers, i, no. 5725 (i) ${ }^{10}$ and ii, no. 1315.20 For Lollardy in London at this period there are the entries in the Episcopal Register relating to cases in 1509 and. 1511, of which those concerning Joan Baker, whom Hunne was accused of defending, are printed below (no. I); and there is also a good deal of scattered information ${ }^{22}$ to be gathered from Foxe, the London chroniclers, the Chancery Significations at the Record Office, and the records of ecclesiastical courts.

For the trial of Hunne there is a series of five documents, four of which, however, appear to be extant only in the pages of Foxe. ${ }^{23}$ In using them one has to remember that his summaries are trustworthy only up to a certain point : he does not insert what is not in the original, but he often omits particulars there given, especially charges accusing the heretics of opinions he did not share. ${ }^{24}$ (1) A summary of the articles objected against Hunne when he appeared before the bishop of London, 2 December 1515. (2) A summary of a notice read by the preacher at Paul's Cross the Sunday after his death (i.e. 10 December), containing additional articles collected from the prologue of his English Bible.25 (3) A summary of the rules drawn up for the

11 Referenoes to some of this will be found in the Victoria History of London, i. $248-50$.

14 Extracts from these were printed in 1847 by Archdeacon W. H. Hale, in $A$ Beries of Precedents and Proceedings, 1475-1610; 800 pp. 64-87. Compare Colet's Convocation Sermon of 1512.

10 The original of this cannot now be found at the Record Office.

to This is the seme document as vol. $i$, no. 5725 (ii), and it may be connected with the Parliament of 1512-14 instead of that of 1515, and so be an antecedent instead of a conequence of Hunne's caso.

"Those concerning the other case, that of Elizabeth Bampson, are printed in The Reign of Henry VII from Contemporary Sources (edited by A. F. Pollard), iii. 242-a. i. 234-8.

- I collected some, but by no means all, of this in the Victoria History of London,

- Acts and Aonuments (ed. 1837-77), iv. 183-4, 186-90.

14 See ibid. Pp. 174-5. Foxe's summary of the charges against Elizabeth Bampeon (ibid. p. 126) omits those accusing her of erroneous belief with regard to the ascension of Christ and the resurrection at the Last Day.

2s All of the were evidently derived from the General Prologue prefixed to some of the existing copies of what is usually called 'the second Wyoliffite version' (see the Church Quarterly Review, li (1901), 291-6), though either Hunne's glose, or the compiler of the articles, or Foxe in summarixing them, made a statement about the secrament of the altar more definitely 'heretical ' than those in the original. It has been ong. gested that a manuacript of that version now in the library of Corpas Christi College, Cambridge (see Dr. M. R. James's Catalogue, i. 336) is the actual copy that belonged to Hunne, on the ground that cortain passages marked, in a hand said to be that of Blythe, bishop of Liahfield and Coventry from 1503 to 1530, correspond to some of those collected by his accusers. But Blythe is nowhere mentioned (though other bishop beaides Fitrjames are) in connerion with Hunne's case; and Mra W. J. Harrison, who has kindly examined tho manusaript for me, finds that the correspondence is by no means wo exact as to warrant wuch a deduction Some of the pasases which are the originals of the thirteen articles in Fore's enmmary are not 
procedure at his condemnation, 16 December. (4) The bishop's sentence against him, which gives a good deal of information about the case. (5) The bishop's letter relinquishing his body to the secular power (16 December), lately discovered by Miss E. J. B. Reid at the Record Office, and printed in full below (no. II).

These documents, however, deal only with the case of heresy : for the circumstances of Hunne's death and the agitation which followed the authorities are of a different character. The earliest is a letter dated 3 March 1514-15 to the papal collector for England, Cardinal Hadrian de Corneto, from his London representative, Polydore Vergil, who was trying to prevent Ammonius from securing the collectorship. In the well-known summary of this in the Letters and Papers, Henry VIII, ii, no. 215, the allusion to Hunne is barely recognizable and appears disconnected from the rest of the letter, but in the original ${ }^{26}$ the connexion is clear. The unseemly contest had been going on for some time; Ammonius had begun to grant dispensations, in spite of an inhibition, ${ }^{27}$ and had lately been aided by papal briefs to the king and the bishop of Winchester (Fox) in one of which were "multa inconsiderate explicata que possent gignere in Ecclesia dei scandalum ingens'. The king and Wolsey were on his side, but Fox supported Polydore Vergil, and before 15 February had written in reply to the Pope

bonas literas quibus palam docuit quanta afficiamur iniuria, quantumque scandali ex ista re hic ortum sit. Et presertim nunc propter unum hereticum nuper a londoniense episcopo poena mortis affectum populo passim in Clerum reclamante, et iam ism seviente, nisi Maiestas Regia furorem compesceret.

The first printed account of Hunne's case is in the second edition of the contemporary chronicle in Richard Arnold's Customs of London, c. 1521. There are references to it in Simon Fish's Supplicacyon for the Beggers (c. 1528) and Sir Thomas More's Supplycacyon of Soulys. In More's Dyaloge a whole chapter is devoted to a discussion of it, which is mentioned in Tyndale's Answere (1531). All these sources of information are of course independent of the tract, and so probably is the account in Wriothesley's chronicle. Later than the tract are the two paragraphs introducing the reprint of it in Hall's chronicle (1542 ?); the account in book xxvii of Polydore Vergil's history

marked, and there are marks against many which are not represented there. Hunne's Bible was popularly supposed to have boen destroyed with his body, but More (Dyaloge, book iii, ch. Iv) states, 'whyther the boke be burned or secretely kepteI can not surely saye.'

t" Cotton MS. Vitellius B. ii, fo. 123 (old numbering: 148 new). Some words missing in the sentences quoted have been supplied from Ammonius's copy on fo. 127 (164).

"The 'certain legal documente' of the Letters and Papers include ' unam dispensationem ab harenario poet inhibitionem factem, insolenter conceasam'.

VOL. XXX.-NO. CXIX. 
(1555), ${ }^{28}$ which is particularly interesting as giving the impression left upon the mind of a foreigner who was living in London at the time ; and the few additions (apparently gathered from papers belonging to Hunne's grandson $)^{29}$ made by Foxe in the second edition of the Actes and Monumentes (1570) to the information he derived from Hall (including the tract) and from the London Episcopal Registers. One of these additions refers to the efforts made to bring about the restoration of Hunne's property (which would have been forfeited to the king as that of a condemned heretio ${ }^{30}$ ) to his children. With this object two bills were introduced into parliament in the spring of 1515 . The entries concerning them are very inaccurately printed in the Journals of the House of Lords, but the one in which the sense is most seriously affected has lately been printed from the manuscript by Professor A. F. Pollard. ${ }^{31}$ Two documents at the Record Office ${ }^{32}$ throw some light upon this aspect of the case: a grant dated 1523 to Hunne's daughter, Margaret Whaplod, and her husband, of all her father's property ; and a petition to Cromwell, not earlier than 1536, from which it appears that she and her family were then in poverty. Her husband seems to have been administering some at least of the property about $1529,{ }^{33}$ but it is possible that the family did not recover it all, and that an endeavour to obtain redress in another direction led to the composition of an undated letter, printed by Foxe, purporting to be a royal order to Dr. Horsey to compensate Hunne's children for the death of their father and the waste of his goods. Brewer doubted and Gairdner denied the authenticity of this, but the latter suggested that it may have been a draft to which it was desired to obtain the king's signature. ${ }^{84}$

16. 645 .

- Acts and Monuments (editions 1837-77) iv. 198.

* By 2 Henry V,ch. 7. If it had bean decided that Hunne committed suicide, the property would have been forfeited to the city (Historical Charlers of the City of London, edited by W. de G. Birch, p. 53). On the other hand, unless he pere protected by 'benefit of clergy', Dr. Horsey's goods would have been similarly forfeited if he had been convicted of murdoring Hunne, and by the custom of the city they ought to have been seized and pat in oharge of one of the eheriffs after the inquest. See above, p. 478, n. 12.

1 Transactions of the Royal Hist. Boc., 3rd series, viii 37-8. Professor Pollard bas pointed out to me that Gairdner (op. cit. p. 40) misunderstood the entry for 3 April. The king's signature nas not 'prematare', since the bill affeoted his interests, and 'deliberetur' here means 'should be discharged' (i. e. thrown out).

- Summarized in Letters and Papers, Henry VIII, II. ii, no. 3062 (4) and vol. Xv, no. 1029 (65). The editors of Fore (Townsend's and Pratt's editions, iv. 725) refer to the latter by its number under the old olassification, among the Chapter House Papars.

- Fore, v. 27.

14 Ibid. iv. 197-8; Letters and Papers, Henry VIII, II, no. 3, n. ; The English Church in the Sizteenth Century, pp. 39-40. It is to be regretted that this letter, if admitted to the Letters and Papers at all, was inserted as early as 1515. Fore was, of course, wrong in describing it as a prarrant 'to redeliver all the said goods', since Hunne's property could not in any case have fallen into the hands of Dr. Horsey. 
One more authority remains to be considered : Keilwey's wellknown account of the controversy in 1514-15 about the privilege of benefit of clergy, ${ }^{35}$ by the use of which Horsey 'fuit preserve hors del temporals maines . . . iesques a le temps que le graund rumor del dit Hunne fuit ascunment abate, et que ils ussent fait son peace oue le roy pur le dit murder.' ${ }^{36}$ This seems to have been accepted almost without qualification by F. W. Maitland, ${ }^{37}$ whose verdict on such a point can hardly be questioned ; but it may be noticed that the dates indicated in it are difficult to reconcile with those to be gathered from other sources for the events of the years 1514 and 1515 .

Nevertheless, however doubtful the chronological details may be, it is certain that it was during the same parliament as discussed the question whether Hunne was murdered in a bishop's prison thet

periculosissime seditiones exorte sunt inter Clericum et Secularem Potestatem, super Libertatibus Ecclesiasticis, quodam fratre Minore nomine Standishe omnium malorum ministro ac stimulatore. ${ }^{28}$

The coincidence was not merely one of time. Standish was doubtless encouraged to maintain an opinion contrary to that of the 'spiritualty' in general by the knowledge that he had the city behind him. At least twice within the last century friars had been accused of heresy for supporting the citizens in their quarrels with the 'curates' or parochial clergy, ${ }^{39}$ and Hunne's case was an incident in such a contest. Moreover, Standish was defending an act which limited the jurisdiction of the ecclesiastical courts, and Hunne had tried to invoke the statute of Praemunire against one of those courts, while the cireumstances of his death had involved in the gravest suspicion two of their officials. It is significant that the contemporary chronicler Arnold, himself a London citizen, specially mentions 'the temperall Lawe' as responsible for the verdict of the inquest, while 'the spirituall Lawe' condemned Hunne as a heretic. Probably the mass of his fellow citizens never regarded him as a heretic at all, in spite of the pains their bishop took to convince them. The impression remaining in London may be summed up in the words of the later chronicler Wriothesley : 'Hunn ... was made an heretique for

"Relationes quorundam Casum (1602), fo. 180'-185".

"Ibid. fo. 185".

" Roman Canon Law in the Church of England, pp. 87-9. Also by Gairdner, op. eit., p. 43. Bat cf. Brewer, Letters and Papers, Henry VIII, ii. no. 1313, n. In his introduction, however (pp. carxii seqq.), Brewer also seems to accept the report as substantially accurate.

2 Journals of the House of Lords, i. 57; cf. Letters and Papers, Henry VIII, IL i, no. 1312 (vi).

* Victoria History of London, i. 248, 249 ; cf. 238. 
suinge a Praemunire.' 40 His suit would have been watched and discussed as a test case, the result of which affected every one of the citizens ; 4 he, like Standish, was a champion in whose fate they were all interested. Significant, too, is the personal intervention of Henry VIII in the affair, ${ }^{42}$ for it may be that the unsuccessful effort made by a London citizen to wield the great weapon of praemunire first suggested to the young king its possibilities in other and mightier hands. ${ }^{43}$

Thus the history of the Reformation in England has to take account of Richard Hunne, not chiefly because of his connexion with the latent Lollardy whose existence may have been not without effect upon its course, nor even because he took a prominent part in that contest between the London clergy and their parishioners which embittered their relations during some of its most critical years : but because his case was an episode in the conflict between the two jurisdictions, spiritual and temporal. It can only be rightly considered in relation both to the case of Standish and to the obscure parliamentary history of the years 1512-15, when began the dissensions which, though stifled for a time by Wolsey, were to end in the complete defeat of the spiritualty in the parliament of $1529-36$.

E. Jefrrites Davis.

I.

London Episcopal Rogister Fitzjames, fo. 25,

Articuli Crimen heretice pravitatis concernentes contra Johannam Bakar uxorem Gervasii Bakar parochie sancte Margarete in Brigestrete civitatis london' super crimine heresis suspectam obiecti et per eam confessati.

First we lay Inquire and aske of the the forsaide Johan that thow art Abydyng and dwellyng within the parishe of saint Margaret in Brigestrete

41 Chronicle (Cemden Soc.), i. 9 ; cf. Keilwey, op. cit., fo. 182, and Fish, Supplicacyon for the Beggers (Early Engl. Text Soc.), pp. 8, 12, and note the pains taken by Bir Thomas More in his Supplycacyon of Soulys and Dyaloge to deal with this point. More's reiterated assertion that Hunne was cited for heresy before he began the suit of praemunire can be accepted without affecting the argument above, since the accusation of heresy may not have attracted much attention until the praemunire suit had brought him into publio notice. But compare the aseertion in the bishop's sentence (Fore, iv. 189) that when he was first summoned before convocation 'apprehendi non potuit'. Possibly the officials dared not arrest him just then.

"1 Compare what More says in the Dyaloge of Hunne's hope to become famous by the result of the praemunire suit, "and haue his matter in the yeres and termes called Hunnes case.'

- See Polydore Vergil's letter, oupra, p. 481 ; his Anglicae Historias Libri rxvii (1555), p. 645; More's Dyaloge, book II, oh. IV ; Hall, Chronicle (ed. 1809), p. 573.

- A few months later the judges decided that the members of convocation who had taken prodings againgt Standish "fueront en lo del Premunire facias etc." Keilwey, op. cit., fo. $184^{\top}$. 
of london and by reason thereof, art of my forsaid lorde of london diocese and jurisdiccion, fatetur

Also we lay and purpose to the that thow art cristenyd and expresly professid unto the holy faith of Criste and to the determinacions of our moder holy church And by reason of this holy sacrament of Baptyme and profession unto the saide holy Faith and religion of crist, thou hast utterly renuncied all manor of false errors, erronyows doctryns and opynyons contrary and a gaynst the determinacions of our moder holy church, fatetur hunc articulum \& omnia \& singula in eodem contenta

Also we lay and object a gaynst the that it is not lefull for the nor eny other and most specially lay person for to make dowghtes reason or dispute pryvyly or opynly of the faith of criste or of the determinacions of our moder holy church or of the absolute power of our holy father the pope or for to move or holde ony erronius opinions disputacions or questions a gaynst the determinacions of holy church, fatetur etiam hunc articulum \& singula in eodem contenta

$A l s o$ we lay and object a gaynst the, that every cristened person, man and woman, techyng, preching, instructyng upholdyng defendyng or belyvyng of the articuls of the Faith and determinacions of our moder holy church, other wyse then our said mother holy church holdith techith prechith instructith upholdith defendith and belyvyth, or makith any new erroneus exposicion determinacion of opinions or pretense lernyng obstinatly contrary unto the saide Articules and determinacions of holy church is an heretik and as an heretyk to be takyn holden and reputed, ad hunc articulum respondet affirmative

$A l_{s o}$ we lay and objecte to the and a gaynst the that every heretike so frowardly erronensly and obstinattly belevyng theching preching or defendyng and dampnabley goyng from the trew determinacions of our moder holy church is in the same dede doyng excommunicat and acursed be the law, fatetur eciam hunc articulum \& omnia \& singula contenta eiusdem

Also we lay and object a gayn the that thow knowist or belevyst that in the parish of saynt Margaret a fore said and in other placis of the city of london thou art sore detecte suspecte and defamyd a pon certyn errors and false opinions of herysy as heraftur doth folow, Ad hunc articulum respondet quod non novit nec credit quod est diffemata vel suspecta de heresi infra parochiam sancte Margarete predictam vel alibi, et si sit aliqua fama sive infamia contra eam laborans in $\&$ de premissis quod non fatetur dicit illa infamia incepit ex malis dictis \& relacionibus cujusdam mulieris vocate Odiams Wiff \& curati dicte ecclesie parrochie sancte margarete

$A$ lso we lay and object to the that it belongith to my lorde of london ordinary in this behalf and his officers to examyn correcte and reforme such maters and to punyshe them that be Gilte and culpabill in such maters and crimes and all other, fatetur eciam hunc articulum \& omnia contenta eiusdem

Also we lay and objecte A genst the that thou said to sir John Cawode then beyng parische prist of saint Margarettes a for said in the dwellyng hous their the xviij day of September last past that thow wolde do no 
more reverence to the Crucifyx in the church then thow wold do to a dogg for thei be but stockes and stones etc prout in articulis contra eam porrectis \& propositis

to. 25 b This be the Articuls and opinions that Johan Bakar the wif of Gervis Bakar Citezin and taylor of london inhabitant in the parishe of sainct Margarettes in Brigestret of london did holde

First the saide Johan Bakar saide to sir John Cawode prest then beyng parishe prest of saincte Margaret a bove saide in hur dwellyng hous ther the xviij day of September last past that she wold do no more reverence to the crucifix in the churche then she wold do to a dogg for thei be but stockes and stones

Also she saide unto the saide John Cawod prest that sche was sory that she had gon in so many pilgurmages as to saint Baviors and dyverse other pilgurmages, And they beyng but mawmentes and false goddes

Also Wher as oon Thomas Blake of london Taylor lyyng in hys deth bed shuld have had the crucifyx broght and laide be fore hym as the laudable custome is in the citie, the said John ${ }^{M}$ reportid the saide wordes be fore the saide preest ther then present, that the said crucifix was not to gif confidence nor trust in but as a fals god

Also the said Johan reported be fore the said priste that she cold here a better sermond at home in hur howse than any doctor or priste colde make at poules crosse or any other place

Also the said Johan affirmith that she knew the sacrament of the Alter or any other of the sacramentes better then any curat or prest did

$A l_{s o}$ Wher as the said prest and the said Johan wer in communicacion of the brennyng of the lady yong for suche opinions as she toke the said Johan saide that she dyed a martir be fore god and she be sought god that she myght dy no wors then she did, And then the said sir John said she shulde be brent as she was and as many as takyth hur opinions

Also Wer as oon Sampsons Wiff dwellyng in aldermanbury late was detecte for heresy the said Johan said that she was punyshed for anyng the trewth

Also the aaid Johan affirmyth that ther shall never prest cum butte oon

Also she holdyth oppinion that our holy father the pope hath no pooer to giff no pardon for the salvacion of mannys soule with many other hereticall oppinions which she will be fownd within the examnyng of hur.

\section{Abiuracio dicte Iohanne \\ Bakar de \& super articulis predictis}

In the name of god Amen Be fore Almyghty god the father the sonne the holy gost And all the holy cumpany of hevyn and you master Thomas Heede Doctor of law And Commyssary to the most reverent Fader in god lord Richarde by the sufferance of god Bishop of london myne Ordinary and diocesan my Juge in this behalf sufficiently deputyd and ordeyneyd I Johan Bakar otherwise callid Gervis the wiff of Gervis Barker of of the

“ Sio in Register (for Johan).

4s Sio in Register. 
parishe of saint Margaret in brigestrete other wise callid saint Margarettes in new Fyshe strete of the city of london of my forsaide lordes diocese and jurisdiction Knowlege and opynly confesse that I wrechid Synner lyke no trew cristen women erroneusly and wikkydly contrary unto the Faith of criste and contrary to the laws ordinance and determinacions of holy church fo. 28 oft and many tymys have spokyn publiced rehersed and techid many and dyvers erroneus and dampnable opinions and poyntes And in especiall thes poyntes folowing that is to say that I have said publishid and rehersid that the Images of saintes in the churche of god were but ydolls and not to be worshippid nor honorid And also that the Images of the holy Crucifyx set up in the church of godd for the remembrance \& representacion of cristes holy passion and ower redempcion was not to gef truste ne confidence in ne to be hadd in honor and reverence And also that [I ${ }^{16}$ ofte \& many tyms have spokyn rehersid and tawght many and dyvers oppinions a gaynst goyng of pilgremages unto Images of saintes affermyng myself to be sory that I had goon so many ways in pilgremages as I had doon And also I have spokyn a gayn offeryng to be made unto the Images affermyng that the Images in the churche be set up but of covetesnes of prystes and to make them riche Thes forsaid opinions dampnable in especiall be me confessid with all other in generall a gayns me provyd with all other here before you Master Thomas heed doctor \& commissary before said I utterly forsake all and iche of them and synguler theis my forsaid wyckkyd saynges and oppinions in especisll and all other in generall And do renownce forswere and abjure them and every of them with all oder for ever more Promittyng and I promitt be this writen boke and the holy contentes of the same by $m y^{47}$ here bodely and corporally tochid with $m y$ hand and kyssid with my mowth my self never to returne to them or any of them nor fall to any other nor to reherse or speke any more or to holde and publishe ne teche them or any of them or any other from hens forthe while my lyff shall endure In witnesse herof $I$ have subscribid this present wrytyng and made this signe with my own hand ${ }^{2}$

\section{II}

Chancery Bignifications. File 128. Publio Record Office.

Excellentissimo in Christo principi et domino nostro domino Henrico dei gratia Regi Anglie et Francie et domino hibernie, Ricardus permissione divina London' Episcopus in eo semper prospere regnare, Cujus Regnum et imperium in eternum manet. Vestre regie celsitudinis maiestati tenore presentium innotescimus et certificamus, Quod Nos in quodam heretice pravitatis inquisicionis negocio contra Ricardum Hune, de parochia Sancte Margarete in Brigestrete London' nostre iurisdictionis dum vixit iam defunctum, nuper ventilato rite et legitime procedentes, Quia per acta actitata deducta exhibita et probata atque per dictum Ricardum dum vixit coram nobis iudicialiter confessata, Comperimus et invenimus, dictum

"There is an anintelligible sign here.

"Sic in Register.

- This entry is undated, but from its place in the Register can be assigned with much probability to May 1511. 
Ricardum crimine heresis irretitum et reum fuisse et esse, Ideoque eundem Ricardum defunctum, Ut hereticum pertinacem sive obstinacem impenitentem et super crimine heretice pravitatis reum et convictum condempnavivimus et excommunicavimus, Corpusque suum ecclesiastica carere debere sepultura pronunciavimus et declaravimus, Ac ipsum et corpus sive cadaver suum huiusmodi brachio et potestati seculari iuxta sanctiones canonicas et legitimas laudabilemque huius incliti regni vestri hactenus in hac parte usitatam et observatam consuetudinem commisimus et reliquimus nostram per sententiam iusticia id exigente. Vestre igitur regie maiestati humiliter supplicamus quatenus quod reliquam est pro dei amore et fidei catholice conservatione facere, exequi dignemini graciose. In cuivs rei testimonium Sigillum nostrum presentibus apponi fecimus. Dat' in palacio nostro London' xvi die Mensis Decembris Anno domini millesimo quingentesimo quartodecimo, Et nostre Translationis Anno Nono. 40

\section{An Assessment of Italian Benefices held by the Cardinals for the Turkish War of 1572}

Among the letters and documents of Cardinal Giovanni Ricci (now preserved in the Ricci archives at Montepulciano) relative to the time preceding the battle of Lepanto is the following paper (no. I), of which there are two earlier drafts with slight variations. It was written just before the death of Cardinal Carlo Grassi in 1571, one of the chief promoters of the Christian league under Pius V, as appears from his name being entered in the list and a note begun at the end to say that he was dead, but erased. It gives the taxation of the cardinals in 1571, called a Donation, and the accompanying letters (nos. II-IV), which I print in a translation, account for the manner of expenditure of 40,000 other gold scudi imposed by Pius V upon the twelve monastic congregations of Italy for 1571 to pay for arming the pontifical galleys. ${ }^{1}$ The first letter was written by Cardinal Ricci at the age of 76 , and the summary of the enswer at the end of the same sheet in the original is in the handwriting of Cosimo I, grand duke of Tuscany. The-Venetians are excluded from the donation, Pius V having granted them a separate decree empowering them to exact 200,000 scudi from their clergy for five years. ${ }^{2}$

\section{A. Edith Hewett.}

w For the tert of this document I am indebted to the kindness of Miss Eleanor J. B. Reid.

1 The congregations were the 'Cassinesi, Certosini, Lateranesi, Olivetani, Camaldolesi, del S.S. Salvatore, Vallombrasani, di San Giorgio d'Alga, Cisterciensi, Girolamini, Crociferi, e Celestini '. Gaetano Moroni, Dizionario di Enudizione Slorico Eccleriastico, \&c., xix. 186, art. 'Decime'.

- Ibid. 